\title{
Development of Strategies to Reduce Ventilation and Heating Costs in a Swedish Sublevel Caving Mine-a Unique Case of LKAB's Konsuln Mine
}

\author{
S. Gyamfi ${ }^{1,2} \cdot$ A. Halim ${ }^{3} \cdot$ A. Martikainen ${ }^{1,2}$
}

Received: 7 December 2020 / Accepted: 23 August 2021 / Published online: 30 September 2021

(c) The Author(s) 2021

\begin{abstract}
This paper outlines a unique case of the development of strategies to reduce ventilation and heating costs in Konsuln iron ore mine in northern Sweden. The mine, located just south of Luossavaara-Kiirunavaara Aktiebolag's Kiruna iron ore mine, was developed as a test mine 2018-2020 for the Sustainable Underground Mining (SUM) project. Besides functioning as a test mine, Konsuln also contributes ore production. The existing mine ventilation system was designed for the current production rate of 0.8 million tons per annum (Mtpa). There is a plan to increase this rate to between 1.8 and $3 \mathrm{Mtpa}$ in the future, and this requires the primary fans to be upgraded. Therefore, a study was carried out to determine whether using ventilation on demand (VOD) could avoid this fan upgrade and reduce Konsuln's ventilation and heating power costs in the future. The study also investigated whether using battery electric vehicles (BEVs) along with VOD or as a standalone strategy could further reduce these power costs. In addition, the study analyzed the suitability of heating power reduction strategies presently or previously used in the Nordic countries and Canada to investigate potential additional strategies to reduce the heating power cost, the largest portion of Konsuln's ventilation and heating power costs. The study found using VOD can avoid the expensive upgrading of the existing primary fans and reduce Konsuln's ventilation and heating power costs in the future. Using BEVs can further reduce these costs. Finally, none of the Nordic and Canadian heating power reduction strategies is suitable for Konsuln because they require unique conditions that do not exist in Konsuln.
\end{abstract}

Keywords Energy-efficient · Ventilation on demand (VOD) - Battery electric vehicles (BEVs) - Ventilation power cost . Heating power cost

\section{Introduction}

Konsuln mine is owned and operated by LuossavaaraKiirunavaara Aktiebolag (LKAB), a Swedish state-owned iron ore mining company. The mine is located just south of the famous Kiruna mine, the largest underground iron ore mine in the world in terms of production, with an output of about 26.9 million tons per annum (Mtpa) [1]. Konsuln ore body was extracted using open-pit mining methods in the

\section{A. Halim}

adrianus.halim@1tu.se

1 Luossavaara-Kiirunavaara Aktiebolag (LKAB), Kiruna, Sweden

2 Luossavaara-Kiirunavaara Aktiebolag (LKAB), Malmberget, Sweden

3 Luleå University of Technology, Luleå, Sweden 1970s and underground mining in the 1980s. The mine was then closed because of unfavorable economic conditions. When LKAB set up its Sustainable Underground Mining (SUM) project [2], a new block of the mine underneath the old workings was developed 2018-2020 as a test mine for the project. Besides Kiruna and Konsuln, the company operates another underground mine, Malmberget, and an open pit mine, Svappavaara. All these operations are located in Malmfälten in northern Sweden inside the Arctic Circle. Products from all operations are transported by rail to the ports of Narvik in Norway and Luleå in Sweden where they are subsequently shipped to LKAB's customers. Figure 1 shows the map of all mining operations and exporting ports.

Besides functioning as a test site, the newly reopened Konsuln mine contributes ore production. The mine currently produces about $0.8 \mathrm{Mtpa}$ of iron ore, and this will increase to between 1.8 and $3 \mathrm{Mtpa}$ in the future. At the time of writing, the production rate was still being decided, 
Fig. 1 Map of northern Sweden, Norway, and Finland, showing LKAB's mining operations (Kiruna, Malmberget, and Svappavaara) and exporting ports (Narvik and Luleå)

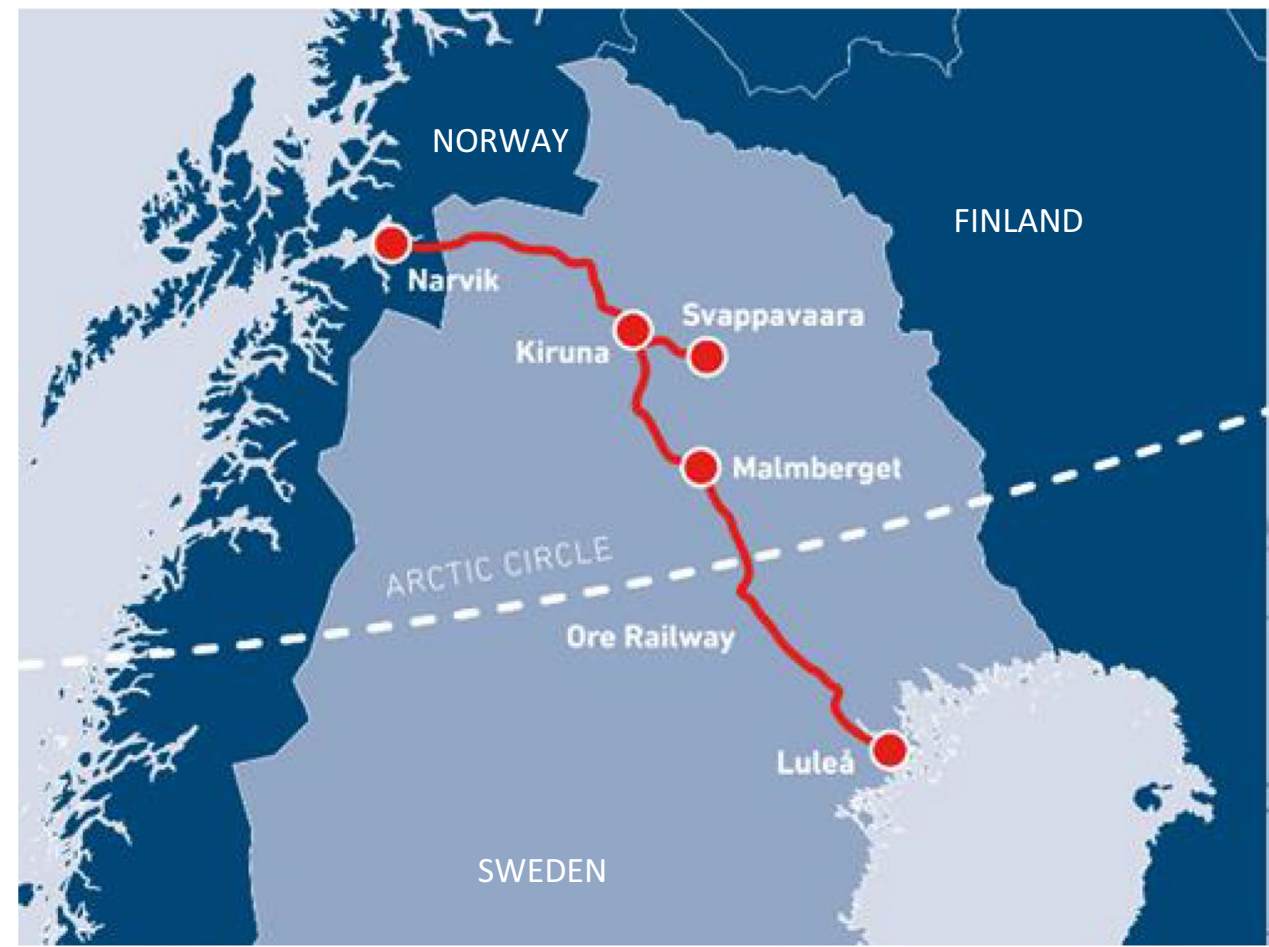

but it will not exceed $3 \mathrm{Mtpa}$. The mine uses the same mining method as in Kiruna mine: sublevel caving (SLC). The mine has three production levels: 436, 486, and 536. The deepest level is about $390 \mathrm{~m}$ below the surface. The ore is transported to the surface stockpile by diesel trucks via a ramp. In contrast, Kiruna mine uses shaft hoisting.

The ventilation and heating system is crucial to ensure the safe and efficient operation of Konsuln mine. The existing system was designed for the current production rate of 0.8 Mtpa with the assumption that all diesel machines required to achieve this rate are in the mine simultaneously. The plan to increase the production rate requires an expensive upgrading of the existing primary fans if similar assumptions are used in the ventilation planning. However, LKAB's new strategy to achieve zero carbon emissions by 2045 discourages traditional planning. Because of this, more sustainable, low-emission technologies and systems are favored in planning for the future. Therefore, a study was carried out to determine whether using an energy-efficient system, in this case ventilation on demand (VOD), could avoid the need to upgrade and also reduce ventilation power costs in the future. Using VOD may reduce heating power costs, as the heating power is proportional to the primary airflow quantity. VOD was selected as the first consideration because it has successfully reduced ventilation and heating power costs in Kiruna and Malmberget mines. Another part of this study investigated whether using battery electric vehicles (BEVs) along with VOD or as a standalone strategy could further reduce power costs. Finally, the study analyzed the suitability of heating power reduction strategies currently or previously used in Nordic countries and Canada to investigate potential additional strategies to reduce the heating cost, the largest portion of Konsuln's ventilation and heating power costs.

The study assumed a production rate of 3 Mtpa and estimated ventilation and heating power costs using VentSim Design software and Excel spreadsheets. Production rate of 3 Mtpa was selected because it is the most challenging design case among all possible production rates between 1.8 and $3 \mathrm{Mtpa}$. With this production rate used as the basis of the study, outcomes can be tailored to the chosen final production rate because it will not exceed 3 Mtpa.

It must be noted that only operating costs can be disclosed in this study due to the confidentiality of capital cost data. However, the authors are allowed to disclose the rough estimation of the payback period in order to show the financial justification of the selected strategy.

Konsuln mine plans to be one of very few ventilation systems to include VOD and BEVs. The only other similar system, to the knowledge of the authors, is in Borden gold mine in Ontario, Canada [3], the first all-electric underground mine in the world where all machines are BEVs. However, the Konsuln case can be considered unique for the following reasons:

- Unlike Ontario (and other provinces in Canada and other major mining countries including Australia, the USA, 
and South Africa), Sweden does not have a specific mining occupational health and safety $(\mathrm{OH} \& \mathrm{~S})$ regulation. Instead, a general OH\&S regulation, Arbetsmiljöverkets författningssamling (AFS), is valid in all workplaces, including mines. Moreover, there is no airflow requirement for diesel mining machines (in $\mathrm{m}^{3} / \mathrm{s}$ per $\mathrm{kW}$ engine rated power) prescribed in the current version of AFS, AFS 2018:1 [4], which was put in force on August 21,2018 . Although there is no airflow requirement for electric mining machines prescribed in either AFS or Ontario's mining OH\&S regulation, the requirement for diesel mining machines is usually the starting point in designing a hard-rock mine ventilation system. The only requirement in Swedish mines is that the prescribed concentration limit for gases and dust and exposure limit for radon given in AFS 2018:1 must not be exceeded. This means Swedish underground mines have flexibility to determine their own airflow quantity, as long as gases, dust, and radon are maintained below their prescribed limits. It must be noted that the concentration limit for gases, threshold limit value-time-weighted average (TLV-TWA), given in AFS 2018:1, must be the same as the TLV-TWA prescribed in the European Union (EU) Directive 2017/164 [5], which was issued on January 31, 2017. This is a requirement because of Sweden's membership in the EU. The TLV-TWA for toxic hard-rock mine gases (from diesel machines and blasting fumes) in Sweden and the EU is $20 \mathrm{ppm}$ for carbon monoxide (CO) and $0.5 \mathrm{ppm}$ for nitrogen dioxide $\left(\mathrm{NO}_{2}\right)$. The limit for $\mathrm{NO}_{2}$ is half of the limit prescribed in the previous version of AFS, AFS 2015:7, which was
$1 \mathrm{ppm}$. The limit for $\mathrm{CO}$ remains unchanged. Because of the significant change of the limit for $\mathrm{NO}_{2}$, the EU granted a transition period until August 21, 2023, for EU mines to take measures to comply with the new limit [6]. Until this date, Swedish mines can still use the limit prescribed in AFS 2015:7. However, the study uses the limit prescribed in AFS 2018:1 because Konsuln will be operational beyond August 21, 2023. Regarding dust and radon, the EU, however, does not currently have a TLV-TWA for respirable dust in workplaces or concentration limit for exposure to radon in underground mines. Therefore, Sweden has determined its own TLV-TWA for respirable dust (straight concentration for respirable fraction of inorganic dust) in workplaces, $2.5 \mathrm{mg} / \mathrm{m}^{3}$, and concentration limit for exposure to radon in underground mines, $2.1 \mathrm{MBqh} / \mathrm{m}^{3}$ per year.

- TLV-TWA of diesel particulate matter (DPM) is currently not prescribed in AFS 2018:1 or in any EU directives. The EU will prescribe the TLV-TWA of DPM as $0.05 \mathrm{mg} / \mathrm{m}^{3}$ of elemental carbon (EC) starting February 21, 2026 [7], and this will have to be adopted by AFS. At present, the Australian TLV-TWA of $0.1 \mathrm{mg} / \mathrm{m}^{3}$ of EC [8] is unofficially adopted by many Swedish mines.

It must be noted that TLV-TWA is only valid for 8 -h working period. For the other working periods, the value of TLV-TWA must be adjusted accordingly.

In order to compare the EU and Swedish limits with those in other major mining countries, they and the other limits are compiled in Table 1.

Table 1 Concentration limit of mine atmospheric contaminants in the $\mathrm{EU}$ and Sweden and other major mining countries. The limit for $\mathrm{NO}_{2}$, $\mathrm{CO}_{\text {, }}$ DPM, and respirable dust is their TLV-TWA, while the one for radon is not

\begin{tabular}{|c|c|c|c|c|c|}
\hline Contaminant/jurisdiction & $\mathrm{NO}_{2}(\mathrm{ppm})$ & $\mathrm{CO}(\mathrm{ppm})$ & $\mathrm{DPM}\left(\mathrm{mg} / \mathrm{m}^{3}\right)$ & Respirable dust $\left(\mathrm{mg} / \mathrm{m}^{3}\right)$ & $\begin{array}{l}\text { Radon (the unit is different } \\
\text { between jurisdictions) }\end{array}$ \\
\hline $\begin{array}{l}\text { The European Union (EU) } \\
{[5,7]}\end{array}$ & $0.5^{*}$ & 20 & $\begin{array}{l}0.05 \text { of elemental carbon } \\
(\mathrm{EC})^{* *}\end{array}$ & $\mathrm{n} / \mathrm{a}$ & $\mathrm{n} / \mathrm{a}$ \\
\hline Sweden [4] & $0.5^{* * *}$ & 20 & $\mathrm{n} / \mathrm{a}^{* * * *}$ & 2.5 (inorganic dust) & $\begin{array}{l}2.1 \mathrm{MBqh} / \mathrm{m}^{3} \text { per year for } \\
\text { underground mines }\end{array}$ \\
\hline Australia [8-10] & 3 & 30 & 0.1 of elemental carbon (EC) & 3 (coal dust) & $\begin{array}{l}\text { Average } 20 \mathrm{mSv} \text { per year } \\
\text { over five consecutive } \\
\text { years with maximum } \\
50 \mathrm{mSv} \text { per year }\end{array}$ \\
\hline Canada (Ontario) $[11,12]$ & 3 & 25 & 0.4 of total carbon (TC) & $\begin{array}{l}0.9 \text { (bituminous coal dust) } \\
0.4 \text { (anthracite coal dust) }\end{array}$ & $\begin{array}{l}2 \text { WLM per quarter } \\
4 \text { WLM per year }\end{array}$ \\
\hline USA[12-15] & 5 & 50 & 0.16 of total carbon (TC) & 1.5 (coal dust) & $\begin{array}{l}2 \text { WLM per quarter } \\
4 \text { WLM per year }\end{array}$ \\
\hline South Africa [16] & 3 & 30 & $\mathrm{n} / \mathrm{a}$ & 2 (coal dust) & $\mathrm{n} / \mathrm{a}$ \\
\hline
\end{tabular}

* Set in 2017 but will be enforced from August 21, 2023

**Set in 2019 but will be enforced from February 21, 2026

***Set in 2018 but will be enforced from August 21, 2023

*****Currently not available but will be 0.05 after February 21, 2026, when the EU limit is enforced 
- The case mine uses sublevel caving (SLC), a method used only by few mines worldwide. The use of this method and the flexibility allowed by Swedish OH\&S regulations allow Konsuln to have significantly less airflow quantity than many other mines worldwide that use the sublevel open stoping (SLOS) method to achieve the same production rate. It must be noted that SLC has higher productivity than SLOS and therefore requires less machines than SLOS for the same production rate. Konsuln's airflow quantity per tonnage of ore produced annually is currently $125 \mathrm{~m}^{3} / \mathrm{s}$ per Mtpa (at a production rate of $0.8 \mathrm{Mtpa}$ ). The successful use of VOD and BEVs will reduce it to a minimum of $33.3 \mathrm{~m}^{3} / \mathrm{s}$ per Mtpa (at a production rate of $3 \mathrm{Mtpa}$ ). These values are significantly lower than typical values in SLOS mines worldwide: 300 to $400 \mathrm{~m}^{3} / \mathrm{s}$ per Mtpa [17].

\section{Konsuln Mine Ventilation System}

Konsuln mine employs a combination of force and push-pull primary ventilation systems. The push-pull system is only used to clear production blasting fumes. After blasting in a certain level, two $22-\mathrm{kW}$ fans bolted to a bulkhead located in the connection drive to the exhaust raises are turned on to pull the fumes from that level. After the fumes are cleared, these fans are turned off, and the system runs on "push" mode during the steady-state production phase. The primary intake fans are two $75-\mathrm{kW}$ EOL Vent system inline axial fans installed in parallel, located $52 \mathrm{~m}$ below the surface. The fans are equipped with variable-frequency drive (VFD) to adjust their speed. A schematic of the primary ventilation system during the steady-state production mode is shown in Fig. 2. A schematic of an example of the blast fumes clearing mode of the system is shown in Fig. 3; in this case, it shows the clearing for level 486 . The dimensions of the primary airways are shown in both figures. Figure 4 shows a ventilation model of the mine, created using VentSim Design software.

The system is designed to supply approximately $100 \mathrm{~m}^{3} / \mathrm{s}$ of fresh air into the mine for a production rate of $0.8 \mathrm{Mtpa}$. This quantity was determined based on a diesel exhaust simulation using VentSim Design software with the assumption that all diesel heavy machines required for a production rate of $0.8 \mathrm{Mtpa}$ are in the mine simultaneously. The machines are fitted with a Euro VI compliant engine (EuroVI is the cleanest emission standard for heavy machine diesel engines sold within the EU and the European Economic Area

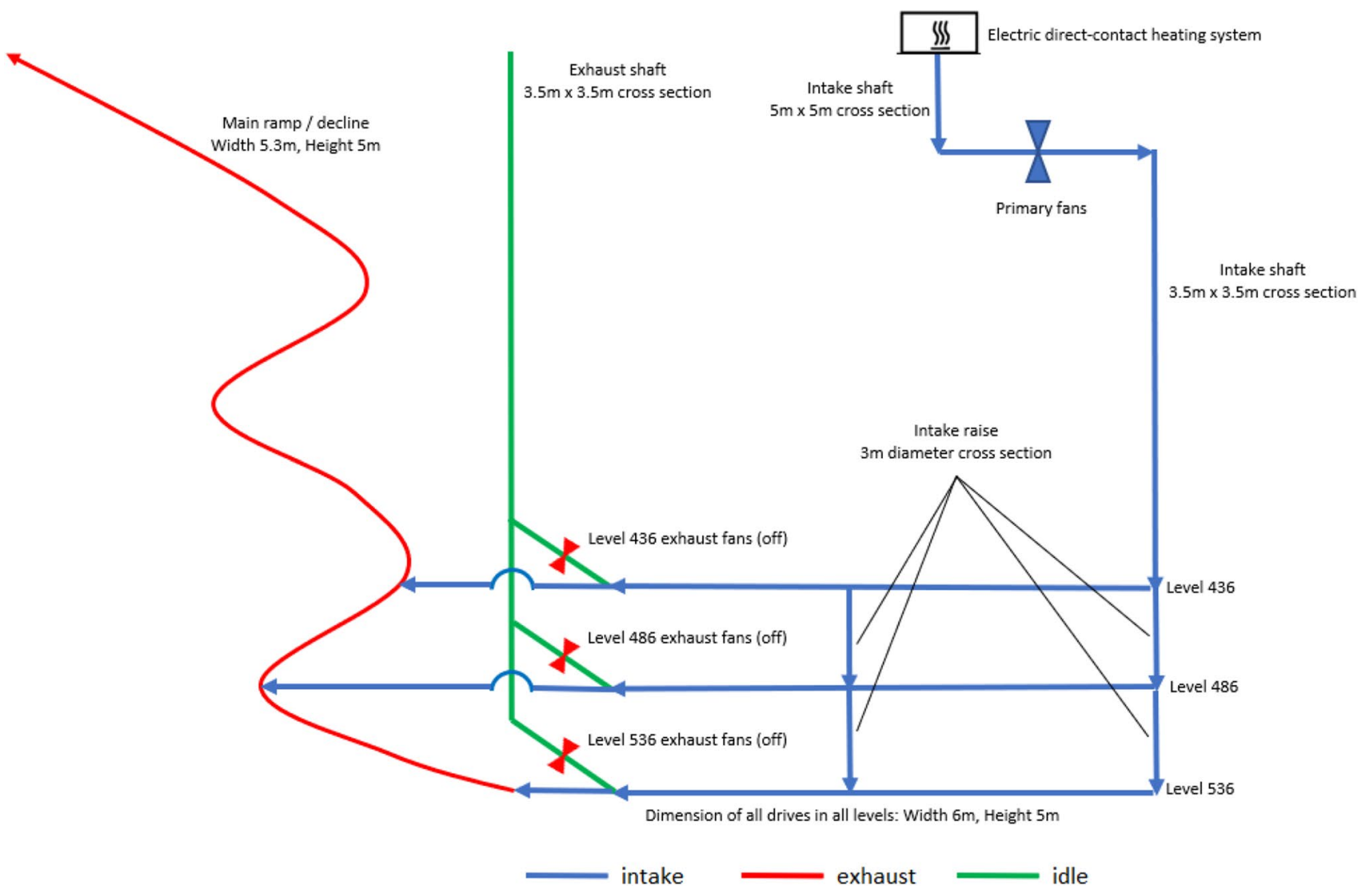

Fig. 2 Schematic of Konsuln primary ventilation system during the steady-state production mode 


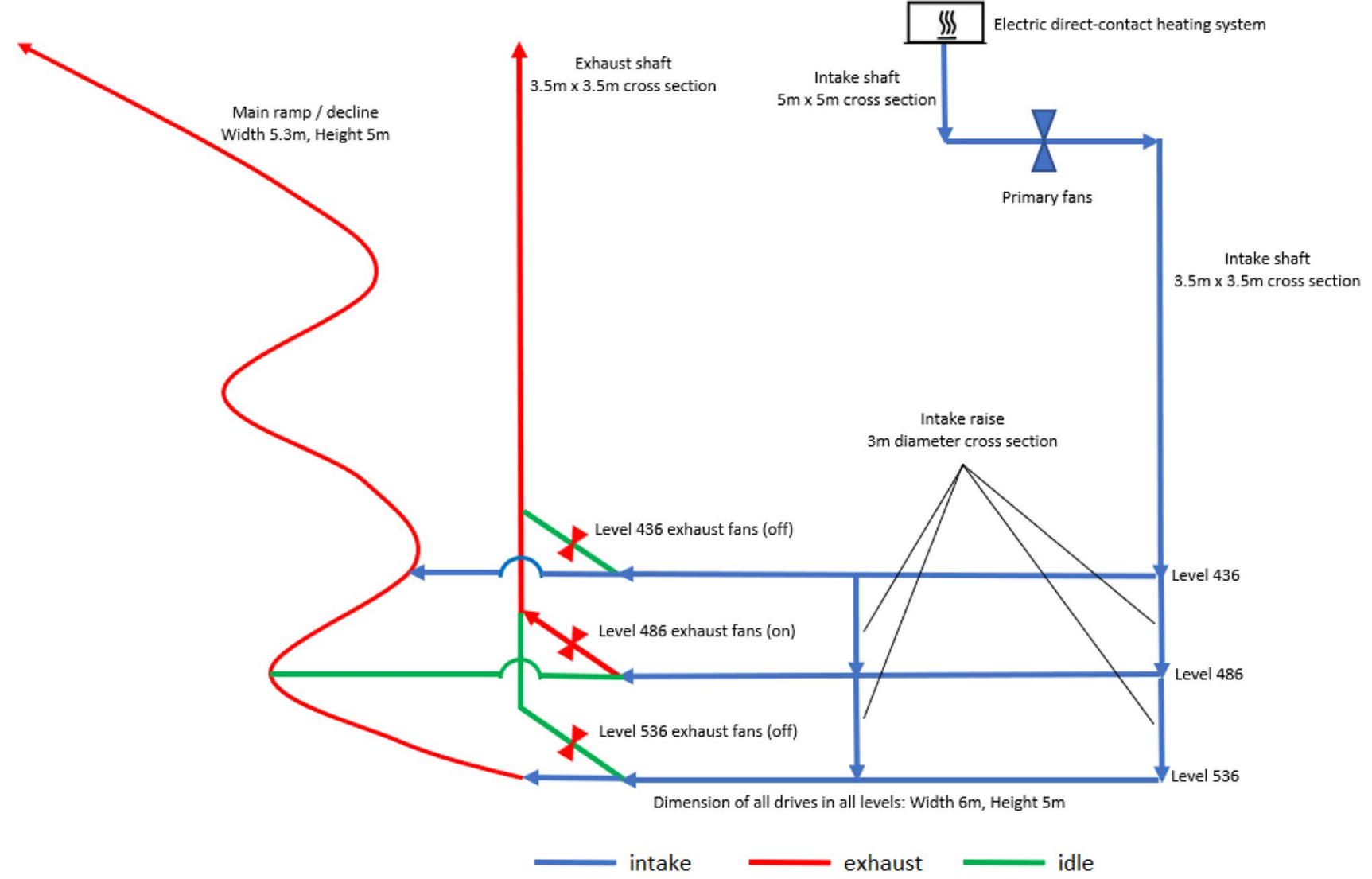

Fig. 3 Schematic of Konsuln primary ventilation system during the blast fumes clearing in level 486

- EEA). As mentioned in the introduction, Swedish mines have flexibility to determine their own airflow requirements. Therefore, LKAB decided to use VentSim Design diesel exhaust simulation to determine Konsuln's primary airflow requirements. Table 2 shows the fleet of the diesel machines and their placement in the VentSim model. The report that describes this design and the VentSim model used for the simulation do not specify the brand of the trucks. They only specify their payload and their engines' rated power and contaminant yield rate.

Because of the extreme winter climate conditions, the intake airflow must be heated during winter months. Winter in Kiruna typically lasts from mid-October to mid-May. Within this period, the surface ambient temperature ranges from -5 to $-40^{\circ} \mathrm{C}$, with average of about $-20^{\circ} \mathrm{C}$. A direct contact heating system using electric coils is installed on the top of the primary fans' intake shaft, as shown in Figs. 2 and 3 , to heat the intake air to $2{ }^{\circ} \mathrm{C}$ to prevent ice buildup within the intake shaft and inside the mine. Figure 5 shows a photo of the building housing this heating system at Konsuln mine.
Airflow in each level is provided by three $30-\mathrm{kW}$ secondary fans bolted to a bulkhead located in the connection drive to the intake raises. These fans are equipped with VFDs to vary their speed and to synchronize them with the primary fans that are also equipped with VFDs. Each fan is connected to a 1000-mm-diameter duct that extends to the end of a section of the level footwall drive and delivers 13 to $14 \mathrm{~m}^{3} / \mathrm{s}$ of air into the duct at its maximum speed. This air is then distributed to each crosscut (production drive) using an 11-kW secondary fan (called a crosscut fan), also equipped with a VFD to synchronize it with the secondary fan that delivers airflow to it, connected to a 800-mm-diameter duct installed in the access to each drive. Like the primary ventilation system, the level ventilation system was designed based on diesel exhaust simulations using VentSim Design software with the assumption that a Sandvik LH621 diesel LHD with a Euro VI compliant engine is operating continuously inside a level. Plan view of level ventilation in Konsuln mine during the steadystate production mode and the blast fumes clearing mode is shown in Figs. 6 and 7 respectively. Both figures show 
Fig. 4 Konsuln ventilation model

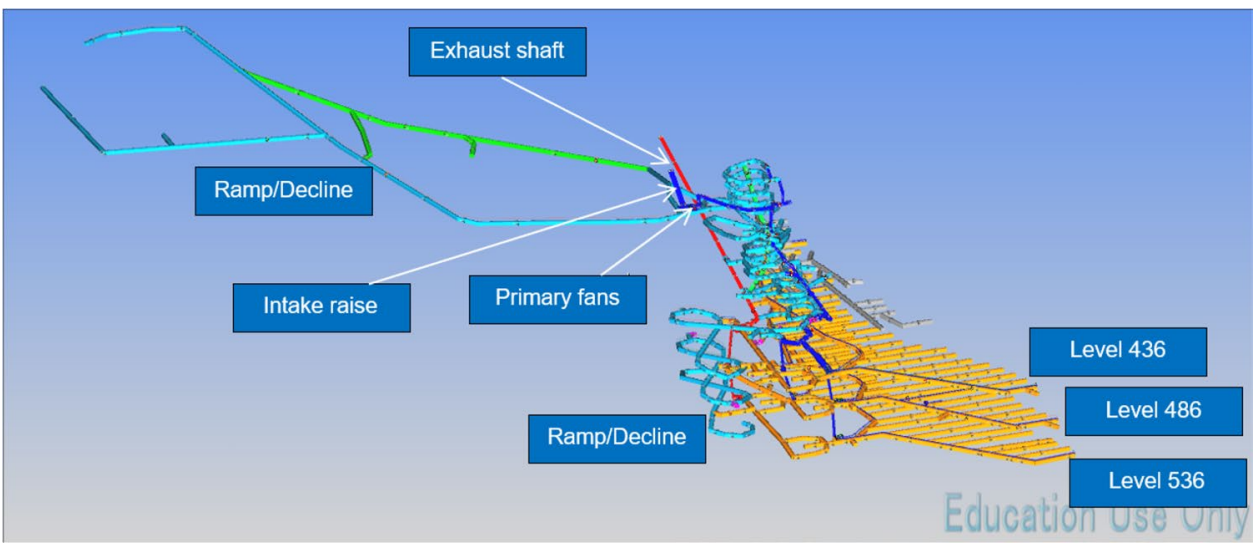

Table2 Fleet of heavy diesel machines required to achieve production rate of 0.8 Mtpa and their placement in the VentSim model used to determine the current design airflow quantity

\begin{tabular}{lll}
\hline Unit & Fleet size & Placement of machines in the VentSim model \\
\hline $\begin{array}{l}\text { Sandvik LH621 LHD (21-ton payload) with Euro VI compliant } \\
\text { engine }\end{array}$ & 2 & One on level 486, one on level 536 \\
30-ton diesel trucks with Euro VI compliant engine & 12 & All trucks travel up and down the main ramp \\
\hline
\end{tabular}

an example of ventilating an active ore drive on the east side of the level.

\section{Possible Strategies to Avoid Upgrading the Primary Fans}

\subsection{Ventilation on Demand}

The ventilation on demand (VOD) concept is for a mine's airflow and distribution to be based upon actual requirements, i.e., air is only supplied when and where needed, and at the appropriate volume for the activity taking place. Historically, mine ventilation systems have been designed for the peak demand (i.e., based on the assumption that all machines are in the mine simultaneously and/or that all areas must be ventilated) and are operated at this maximum level regardless of the actual demand. In reality, not all machines are in the mine simultaneously, and in some mines, inactive areas do not need to be ventilated. This results in significant amounts of wasted airflow and air conditioning and low ventilation system efficiency. VOD can improve the system efficiency and hence reduce the overall airflow requirement, subsequently reducing ventilation power consumption. In mines that require heating like Konsuln, the reduction of
Fig. 5 The building housing Konsuln's direct contact electric heating system

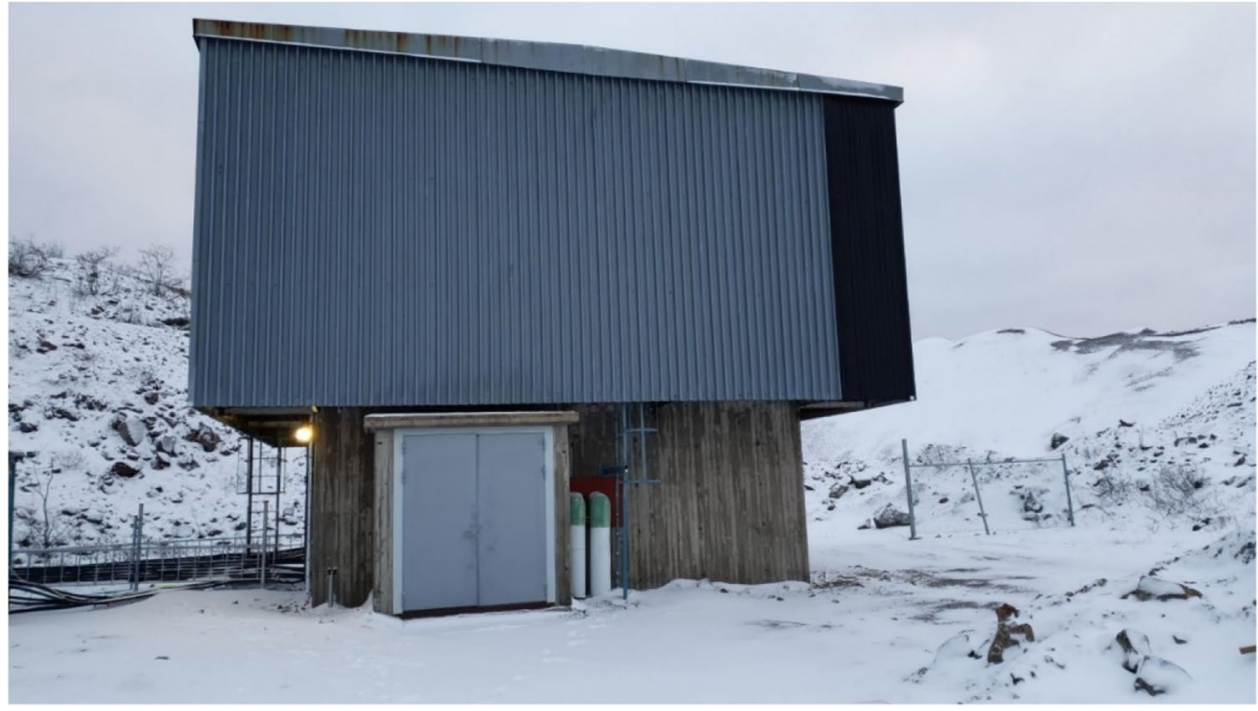


Fig. 6 Plan of Konsuln level ventilation during the steadystate production mode

Fig. 7 Plan of Konsuln level ventilation during the blast fumes clearing mode

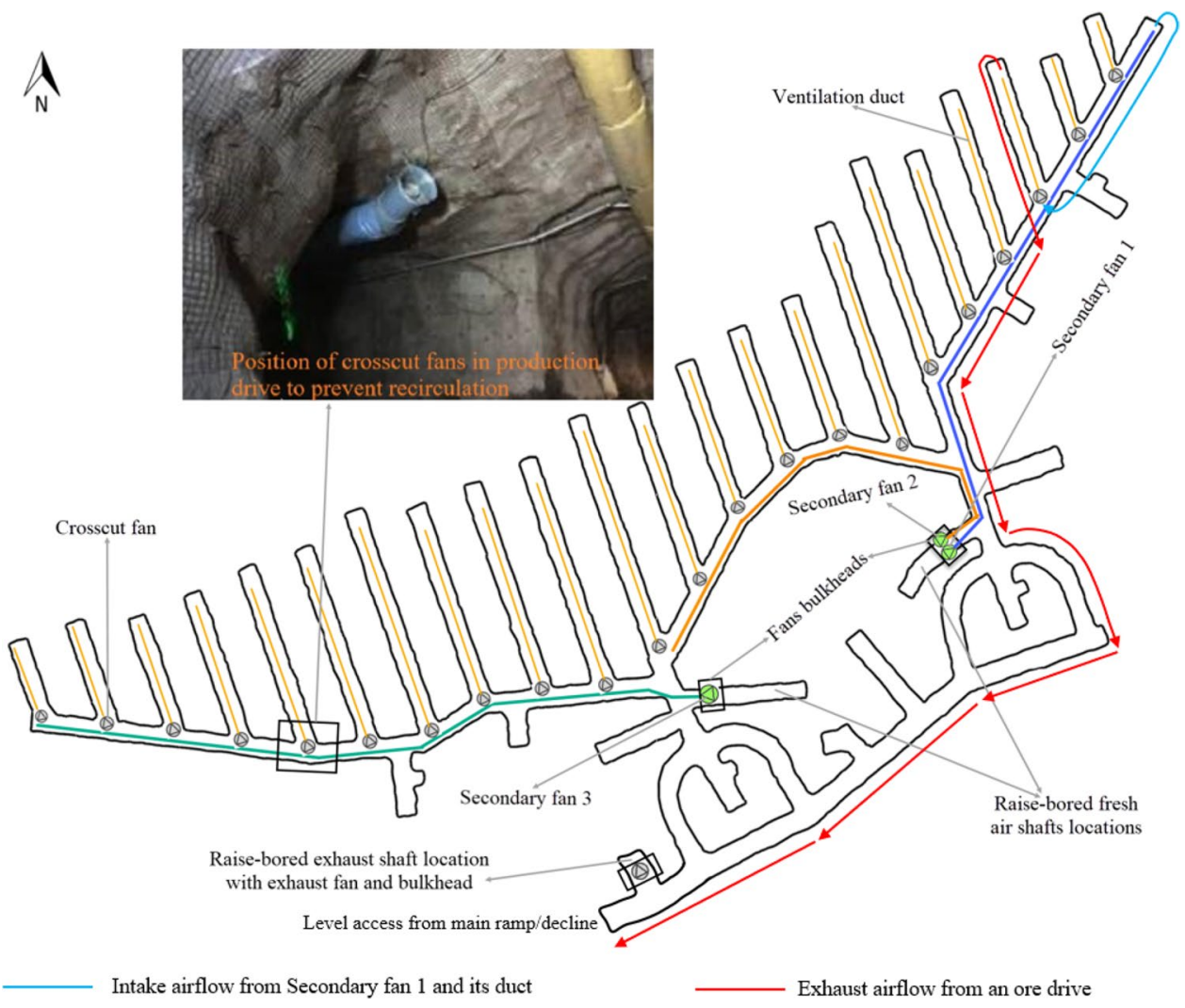

ㅅำ
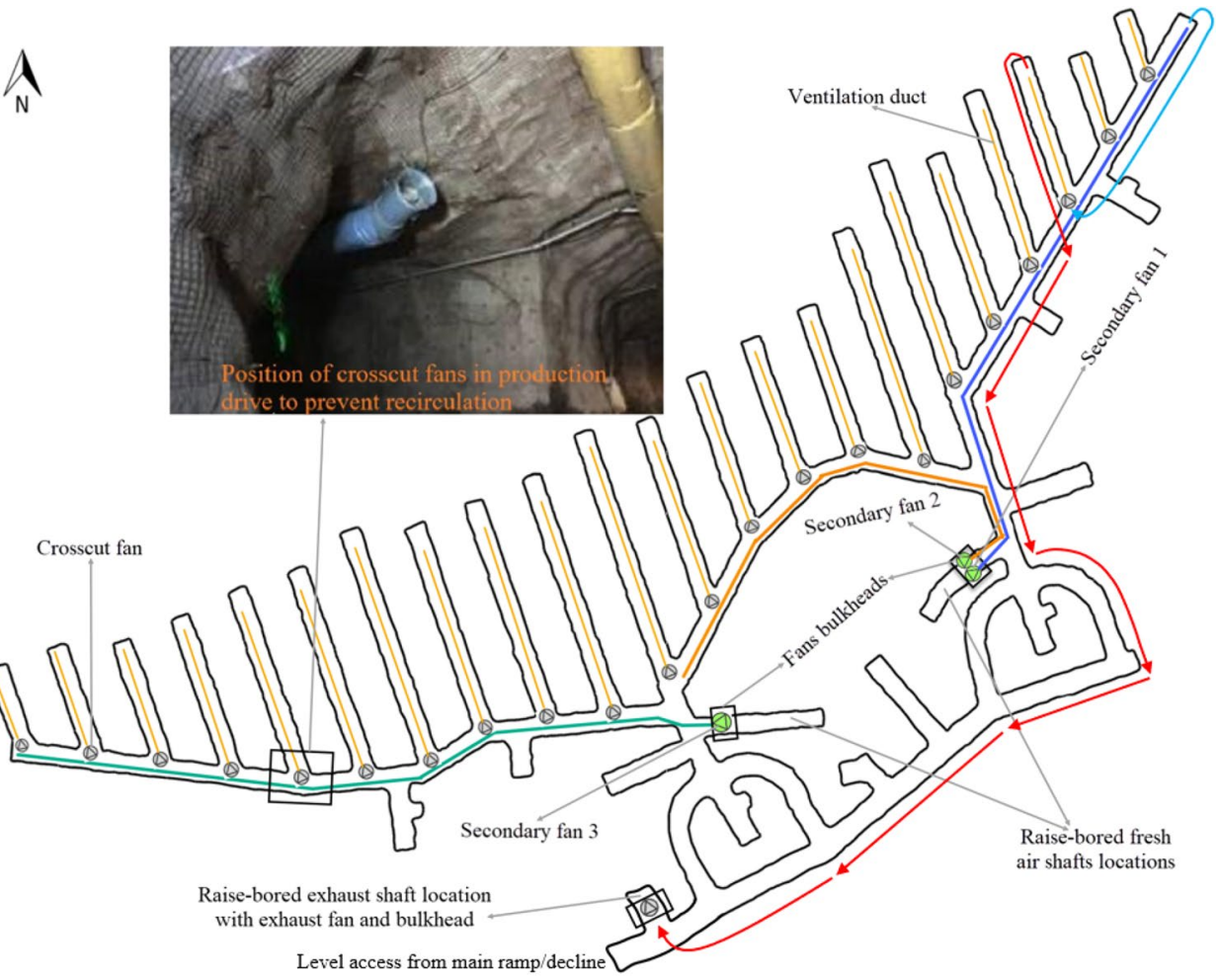

Intake airflow from Secondary fan 1 and its duct

Exhaust airflow from an ore drive 
overall airflow requirements will reduce the heating power cost. This is because the heating power consumption is proportional to the primary intake airflow quantity. Details of VOD are given in other references, such as [6, 18-22]. The system used in LKAB mines is controlled by vehicle detection and gas sensors, as described in [6]. It uses 4th and 5th control strategies of VOD, which are "tagging" and "environmental." The VOD control strategies are described in [22].

However, it must be noted that VOD might not technically be feasible in all mines. Some mines have a significant amount of heat from their surrounding rock mass and/or strata gases, so their inactive areas might have to be kept ventilated. The airflow quantity required for this purpose depends on the amount of heat and/or strata gases present in these areas. Nevertheless, VOD has been proven to be technically feasible in Swedish mines because their virgin rock temperature (VRT) is very low, and the majority do not have strata gases. It must also be noted that VOD requires a significant capital expenditure. However, experience in Swedish mines shows savings in ventilation power costs outweigh the capital investment required to install VOD, making this system popular in Sweden.

\subsection{Battery Electric Vehicles}

Replacing diesel machines with Battery Electric Vehicles (BEVs) has been widely acknowledged by the mining industry worldwide as a critical step to improve working conditions, reduce electrical power cost, and reduce greenhouse gas emissions, all of which are major requirements to keep underground mining sustainable in the future. Unlike diesel machines, BEVs do not produce toxic gases or DPM. They produce significantly less heat and are less noisy than their diesel counterparts. Therefore, replacing diesel machines with BEVs will improve working conditions, improve mineworkers' safety and productivity, and reduce mine airflow requirements, thus reducing mine ventilation electrical power consumption. In mines that require heating like Konsuln, this can ultimately reduce heating power costs.

Only a few underground hard-rock mines worldwide use BEVs, even though they have been available since the 1980s, mostly because the short duration of their battery has meant lower productivity. The recent developments in battery technology allow the manufacturing of BEVs with long battery duration, such as Epiroc Boomer E2 Battery jumbo, Epiroc ST14 Battery LHD, Epiroc MT42 Battery mine truck, Sandvik DD422iE jumbo, Sandvik LH518B LHD, and Artisan (a subsidiary of Sandvik) Z50 mine truck. A field trial of Epiroc's Boomer E2 Battery, ST14 Battery, and MT42 was carried out in Agnico Eagle Finland's Kittilä mine in 2019-2020 as a part of an EU-funded project, Sustainable Intelligent Mining Systems (SIMS) [23]. The machines were tested in Epiroc's test mine in Kvarntorp, Sweden, prior to the field trial. The second author of this paper was involved in the field and test trials and observed that the productivity of these BEVs is similar to diesel machines, and they improve airflow quality in the working areas. The project also investigated the economy of BEVs. Traditionally, BEVs are significantly more expensive than their diesel counterparts because of their battery price. The investigation found Epiroc's business model of Battery as a Service (BaaS) [24], whereby the battery is not sold along with the vehicle but as a "functional sale," similar to leasing, reduces the price of its BEVs significantly. Although they are still slightly more expensive, this is compensated for by their low operating costs. In the end, the overall costs (capital and operating) of Epiroc's BEVs are similar to those of diesel machines [25].

BEVs are seen by many mines in the EU as the most feasible way to address the challenge of complying with the new TLV-TWA of $\mathrm{NO}_{2}(0.5 \mathrm{ppm})$ and the future TLV-TWA of DPM $\left(0.05 \mathrm{mg} / \mathrm{m}^{3}\right.$ of EC). These limits are very low, and many mines consider using diesel machines makes compliance difficult, even if these machines are fitted with a Euro VI compliant engine. Using BEVs would also be in line with LKAB's strategy to achieve zero carbon emissions by 2045. This is why a part of the SUM project includes testing Epiroc's BEVs. LKAB has ordered the BEVs trialed in the SIMS project (ST14 Battery LHDs and MT42 Battery trucks) for the SUM project. Epiroc's next generation of BEVs (ST18 Battery LHDs) will be trialed later in the SUM project.

\section{Methodology Used in This Study}

As mentioned in the introduction, this study was based on a production rate of $3 \mathrm{Mtpa}$. This production rate was selected as the most challenging design case among all possible production rates between 1.8 and $3 \mathrm{Mtpa}$. This means the outcomes of this study can be tailored to the chosen final production rate which will not exceed $3 \mathrm{Mtpa}$.

\subsection{Sequence of the Investigations on the Feasibility of VOD and BEVs}

The first step in this study was determining the sequence of the investigations. Four scenarios were created as follows:

1. A baseline scenario where VOD is not used: this scenario was used to determine whether the existing ventilation and heating system can cater to the most challenging design case (increasing production rate to $3 \mathrm{Mtpa}$ ).

2. A scenario of using VOD and diesel machines: this scenario and the previous scenario were used to investigate whether VOD precludes the need to upgrade the existing 
Table 3 Basis of the baseline scenario

\begin{tabular}{lll}
\hline Unit & Fleet size & Deployment of the units \\
\hline $\begin{array}{l}\text { Epiroc ST18 LHD with } \\
\begin{array}{l}\text { Euro VI compliant engine } \\
\text { Scania R500 diesel trucks } \\
\text { with Euro VI compliant } \\
\text { engine }\end{array}\end{array}$ & $\begin{array}{l}\text { One on level 436, two on level 486, and one on level 536 } \\
\text { One on level 436, two on level 486, one on level 536, } \\
\text { and eight on the main ramp }\end{array}$ \\
\hline
\end{tabular}

fans and heating system and can reduce the ventilation and heating power costs.

3. A scenario of using VOD and BEVs: this scenario was used to investigate whether the ventilation and heating power costs can be further reduced.

4. A scenario of using BEVs only: because VOD requires high capital expenditure, it is necessary to find out whether using BEVs as a standalone strategy meet the same aim as Scenario 3, thus avoiding VOD installation.

The scenarios were based on the fleet selection and production schedule created by LKAB's production planning engineer.

The baseline machines scenario is given in Table 3 . The table shows the total fleet of heavy diesel machines required to achieve a production rate of $3 \mathrm{Mtpa}$ and their deployment in the mine. In other words, this table shows the basis of the planned peak demand of the airflow for the most challenging design case. It indicates that to increase the production rate from 0.8 to $3 \mathrm{Mtpa}$, the truck payload must be increased from 30 to 40 ton. Therefore, Scania R500 trucks were selected for the new production schedule. Their fleet size by number is the same as that required for a production rate of $0.8 \mathrm{Mtpa}$, i.e., 12 units (see Table 2). The production planning engineer also decided to replace LH621 LHDs (21-ton payload) with ST18 LHDs (18-ton payload) in the new schedule. Consequently, four LHDs will be required in the new schedule instead of two. Note that even though an ST18 has less payload than an LH621, it has the same engine power, $352 \mathrm{~kW}$.

The scenario of using VOD and diesel machines is detailed in Table 4. The table shows the deployment of heavy diesel machines that will be in the mine simultaneously to achieve a production rate of $3 \mathrm{Mtpa}$. Only 8 out of 12 trucks

Table 4 Basis of the scenario of using VOD and diesel machines

\begin{tabular}{ll}
\hline Area & Deployment \\
\hline Level 436 & $\begin{array}{l}\text { One Scania R500 truck, one Epiroc ST18 LHD } \\
\text { Level 486 }\end{array}$ \\
Two Scania R500 trucks, two Epiroc ST18 LHDs \\
Level 536 & $\begin{array}{l}\text { Two Scania R500 trucks, one Epiroc ST18 LHD. In this } \\
\text { case, one truck is being loaded, and another is waiting } \\
\text { in the queue }\end{array}$ \\
Main ramp & Three Scania R500 trucks \\
\hline
\end{tabular}

will be in the mine at one time, based on the experience that all trucks are very seldom in the mine at the same time. In other words, the table shows the basis of the planned actual demand of the airflow for the most challenging design case.

The scenario of using VOD and BEVs was created by replacing diesel machines in Table 4 with their equivalent BEVs, i.e., those with a similar payload, as shown in Table 5. The selected BEVs are Epiroc MT42 Battery trucks (42ton payload) and Sandvik LH518B LHDs (18-ton payload). They were selected because at the time of writing, they were the only BEVs in the market with a payload similar to that of the diesel machines in Tables 3 and 4. Moreover, LKAB has ordered MT42 Battery trucks to be used in Konsuln, as mentioned previously. Their productivity is assumed similar to that of the replaced diesel machines based on the observation in the SIMS project mentioned in Sect. 3.2. It must be noted that Epiroc and Sandvik's BEVs use battery swapping, which takes 6 to 10 min to complete, instead of battery recharging. As noted above, ST18 Battery LHDs will be trialed in Konsuln as a part of the SUM project. These machines are currently being manufactured in Epiroc's main factory in Örebro in southern Sweden. Similarly, the basis of the scenario of using BEVs only was created by replacing diesel machines in Table 3 with their equivalent BEVs, as shown in Table 6.

\subsection{Estimation of Ventilation Power Cost Using VentSim Design Software}

The ventilation power cost, including primary and secondary fans, was estimated by running simulations with VentSim Design software for all scenarios described in the previous section. The model was calibrated beforehand, as described in [26]. The fleet deployment shown in Tables 3 to 6 used the Activity Tracks function in VentSim Design. The waiting truck in level 536 shown in Tables 4 and 5 was assumed to turn off its engine and therefore emits negligible contaminants and heat; hence, it was excluded from the VentSim simulations.

Three types of simulation were performed for the baseline scenario and VOD and diesel machines scenario: diesel exhaust, heat, and radon. Two types of simulation were carried out for VOD and BEVs and BEVs only scenarios: heat and radon. Input data for these simulations are shown in Appendix 1. 
Table 5 Basis of the scenario of using VOD and BEVs

\begin{tabular}{ll}
\hline Area & Deployment \\
\hline Level 436 & One Epiroc MT42 Battery truck, one Sandvik LH518B LHD \\
Level 486 & Two Epiroc MT42 Battery trucks, two Sandvik LH518B LHDs \\
Level 536 & Two Epiroc MT42 Battery trucks, one Sandvik LH518B LHD. In \\
& this case, one truck is being loaded and another is waiting in the \\
& queue \\
Main ramp & Three Epiroc MT42 Battery trucks \\
\hline
\end{tabular}

For the VOD and diesel machines and the VOD and BEVs scenarios, the speed of both primary and secondary fans was varied until the associated atmospheric contaminants and air temperature in all airways fell below their prescribed limits, in each of the simulations mentioned above. For the baseline scenario and the scenario of BEVs only, all fans were run at their maximum speed because VOD was not available.

Another criterion in the simulations was assigning air velocity limits in horizontal airways. There are no prescribed air velocity limits in AFS 2018:1. Therefore, the study used the rule of thumb value for the maximum velocity to prevent dust pickup, $5 \mathrm{~m} / \mathrm{s}$ [17]. The minimum velocity limit was $0.3 \mathrm{~m} / \mathrm{s}$ in simulations for the baseline and the VOD and diesel machines scenarios; this is recommended by McPherson as the minimum limit for airways where personnel work or travel [27]. In simulations of the VOD and BEVs and the BEVs only scenarios, the minimum limit was set to $0.2 \mathrm{~m} / \mathrm{s}$, based on the observation in the SIMS project. During the field and test trials in Kittilä mine and Kvarntorp test mine, it was observed that the heat emitted by BEVs was absorbed immediately by the strata surrounding the airway because the temperature sensors did not detect any increase in air temperature between the upstream side and downstream side of the running BEVs. This is because the strata in Swedish and Finnish mines have very low VRT. Observations in some of these mines have found the strata cool the primary intake airflow to mining depths of about $1 \mathrm{~km}$ below the surface. There was no heat problem encountered when the air velocity was $0.2 \mathrm{~m} / \mathrm{s}$ during the trials.

The total fan power cost associated with setting the primary and secondary fans to meet the above criteria was recorded as the ventilation power cost of the scenario. The unit electrical power cost used in these simulations was 0.7 Swedish crowns (svensk krona, SEK) per kWh (about US\$ 0.08 per $\mathrm{kWh}$ based on the exchange rate in 2021). It was assumed that all fans run non-stop throughout the year.
The concentration limits used in the diesel exhaust simulation were the TLV-TWA for $\mathrm{CO}$ and $\mathrm{NO}_{2}$ as stated in AFS 2018:1 (20 ppm for $\mathrm{CO}$ and 0.5 ppm for $\mathrm{NO}_{2}$ ) and the Australian TLV-TWA for DPM $\left(0.1 \mathrm{mg} / \mathrm{m}^{3}\right.$ of EC). The duration of each working shift in Konsuln is currently $8 \mathrm{~h}$, so these TLV-TWA did not need adjustment. As mentioned previously, no TLV-TWA for DPM is currently prescribed in AFS 2018:1 or in any EU directives, so LKAB adopts the Australian TLV-TWA following the practice of other Swedish mines. The predicted DPM concentrations in this simulation were also compared to the future limit of $0.05 \mathrm{mg} / \mathrm{m}^{3}$ of EC to see whether the mine would be able to comply with AFS, with respect to DPM, after February 21, 2026.

As mentioned above, the concentration limits for diesel exhaust gases and DPM used in Konsuln are currently based on 8-h working shifts. However, the working shifts may become longer in the future. Therefore, this study also used the limits based on the longest possible working shift, $12 \mathrm{~h}$, in the diesel exhaust simulations: $10 \mathrm{ppm}$ for $\mathrm{CO}, 0.25 \mathrm{ppm}$ for $\mathrm{NO}_{2}, 0.05 \mathrm{mg} / \mathrm{m}^{3}$ of $\mathrm{EC}$ for the current DPM, and $0.025 \mathrm{mg} / \mathrm{m}^{3}$ for the future DPM after February 21, 2026. These limits were calculated using the Brief and Scala method, where they were calculated as half of their TLV-TWA. The calculations are shown in Appendix 2.

Heat simulation was carried out to find areas that might pose a heat stress risk. AFS 2018:1 does not include a limit for temperatures in underground mines, because until now, no Swedish mines have had heat issues. This is also the reason why heat was not simulated in the design for a production rate of $0.8 \mathrm{Mtpa}$. This simulation used the limit of $27^{\circ} \mathrm{C}$ wet bulb (WB), the typical lower limit of hot working conditions used in other countries, including Australia and South Africa. This simulation was carried out under summer conditions.

Radon simulation was carried out to find whether exposure would exceed the limit specified in AFS 2018:1, 2.1
Table 6 Basis of the scenario of using BEVs only

\begin{tabular}{lll}
\hline Unit & Fleet size & Deployment of the units \\
\hline Sandvik LH518B LHD & 4 & $\begin{array}{l}\text { One on level 436, two on level 486, and one on level 536 } \\
\text { One on level 436, two on level 486, one on level 536, } \\
\text { and eight on the main ramp }\end{array}$ \\
\hline
\end{tabular}


$\mathrm{MBqh} / \mathrm{m}^{3}$ per year. Radon is present in Konsuln because its ore body contains small amounts of uranium minerals. During the production in the old workings in the 1980s, radon exposure in the mine was found to be insignificant. Therefore, it was not simulated in the design for a production rate of $0.8 \mathrm{Mtpa}$. However, it was simulated in this study to ensure it would not be an issue in the future. Since VentSim Design only calculates radon concentration in becquerel per liter, the exposure was calculated by converting the concentration to becquerel per cubic meter, then multiplying it by Konsuln's current annual working period of $1804 \mathrm{~h}$.

Dust was not included in the simulation because the best method to control dust is to prevent it from becoming airborne at the source (e.g., drill rigs, drawpoints, transfer points, road surfaces) rather than diluting it with ventilating airflow. Dust is usually suppressed by spraying these sources with water or dust suppressant. Many practitioners agree ventilation alone is not sufficient to manage dust. In fact, supplying too much airflow can worsen the situation because turbulence in the airflow, which is proportional to the airflow quantity, can keep the majority of the dust airborne. Therefore, it was assumed the majority of dust was suppressed by the dust suppression system and was not airborne in this simulation.

The condition simulated was the steady-state production phase. This means the primary ventilation system was operated as force system in the simulations (the level exhaust fans were turned off, as they are only used to clear blasting fumes). It must be noted that machines and non-blasting crew are not allowed to enter the mine during the clearance of production blasting fumes.

\subsection{Estimation of Heating Power Cost}

The heating power cost saving in each scenario was estimated by first calculating the required heating power using the following equation:

$q_{a}=m_{a} C_{p} \Delta t$

where $q_{a}$ is the required heating power (W); $m_{a}$, mass flow of the primary intake airflow $(\mathrm{kg} / \mathrm{s}) ; C_{p}$, specific heat of dry air $(1005 \mathrm{~J} / \mathrm{kg} \mathrm{K})$; and $\Delta t$, dry bulb temperature increase (K).
The mass flow of the primary intake airflow was calculated based on the average winter air density in Kiruna, $1.3 \mathrm{~kg} / \mathrm{m}^{3}$. The increase of the dry bulb temperature reflects the average ambient winter temperature in Kiruna, $-20^{\circ} \mathrm{C}$, to $2{ }^{\circ} \mathrm{C}$. This target temperature is the temperature where icing within the intake shaft does not occur, based on experience in Swedish mines.

The heating power cost in each scenario was estimated by multiplying the required heating power with the average winter duration in Kiruna and the unit cost of SEK 0.7 per kWh. As mentioned in the introduction, winter in Kiruna typically lasts from mid-October to mid-May, corresponding to 212 days annually. Kiruna ventilation personnel informed the authors that the electrical power consumed by the heating system is equal to the required heating power as the heating system is a direct contact system using electric coils.

\subsection{Assessment of Suitability of Nordic and Canadian Heating Power Reduction Strategies}

The study analyzed the suitability of past and present Nordic and Canadian heating power reduction strategies to investigate potential additional measures to reduce the heating cost, as it consumes a significant portion of the overall ventilation and heating power costs. It did so via a literature review. Results are given in Sect. 6.

\section{Results of Ventilation and Heating Power Cost Estimation}

\subsection{Baseline Scenario}

Results of ventilation and heating power cost estimation for this scenario are shown in Table 7 . The values in the table were used as the baseline costs in the following scenarios because they represent the planned peak demand of the airflow for the most challenging design case. Heating power cost is the largest portion of the overall power costs. The highest predicted values of diesel exhaust contaminant concentration, temperature, and radon exposure are shown in Table 8; the table indicates whether they are below or above their limit. The primary intake airflow quantity was simulated as $108 \mathrm{~m}^{3} / \mathrm{s}$, and airflow in each level was simulated as around $36 \mathrm{~m}^{3} / \mathrm{s}$.

As Table 8 shows, the existing ventilation system can still cater to the planned production rate of $3 \mathrm{Mtpa}$ at the peak

Table 7 Estimated annual ventilation and heating power consumption and costs for the baseline scenario

\begin{tabular}{|c|c|c|c|c|c|c|}
\hline \multicolumn{2}{|l|}{ Primary fans' power } & \multicolumn{2}{|c|}{ Secondary and crosscut fans' power } & \multicolumn{2}{|l|}{ Heating power } & \multirow[t]{2}{*}{ Total power costs (SEK) } \\
\hline Consumption (kW) & Cost (SEK) & Consumption (kW) & Cost (SEK) & Consumption (kW) & Cost (SEK) & \\
\hline 102 & 625,464 & 323.5 & $1,983,702$ & 3104.2 & $11,056,075$ & $13,665,241$ \\
\hline
\end{tabular}


Table 8 Highest predicted values of diesel exhaust contaminants concentration, temperature, and radon exposure for the baseline scenario

\begin{tabular}{lll}
\hline Item & Highest value & Area \\
\hline $\mathrm{CO}$ & $9.1 \mathrm{ppm}$ & Main ramp \\
$\mathrm{NO}_{2}$ & $0.11 \mathrm{ppm}$ & Main ramp \\
$\mathrm{DPM}$ & $0.016 \mathrm{mg} / \mathrm{m}^{3}$ of EC & Main ramp \\
Temperature & $25^{\circ} \mathrm{C} \mathrm{WB}$ & Main ramp \\
Radon & $1.4 \mathrm{MBqh} / \mathrm{m}^{3}$ per year & Level 536 \\
& & west foot- \\
& & wall drive \\
\hline
\end{tabular}

Limits: CO: $20 \mathrm{ppm}$ for 8 -h shifts and $10 \mathrm{ppm}$ for 12-h shifts; $\mathrm{NO}_{2}$ : $0.5 \mathrm{ppm}$ for 8 -h shifts and $0.25 \mathrm{ppm}$ for 12 -h shifts; DPM (current): $0.1 \mathrm{mg} / \mathrm{m}^{3}$ of EC for $8-\mathrm{h}$ shifts and $0.05 \mathrm{mg} / \mathrm{m}^{3}$ of EC for $12-\mathrm{h}$ shifts; DPM (after February 26, 2026): $0.05 \mathrm{mg} / \mathrm{m}^{3}$ of EC for 8-h shifts and $0.025 \mathrm{mg} / \mathrm{m}^{3}$ of EC for 12 -h shifts; temperature: $27{ }^{\circ} \mathrm{C} \mathrm{WB}$; radon: $2.1 \mathrm{MBqh} / \mathrm{m}^{3}$ per year

airflow demand for both 8- and 12-h working shifts because diesel exhaust contaminants, temperature, and radon are below their limit. These results are surprising, but they indicate Euro VI compliant engines are so clean that the diesel contaminant emissions remain below their limit even though the number of machines and the diesel power are higher than those used for a production rate of $0.8 \mathrm{Mtpa}$. However, it must be noted that $\mathrm{CO}$ concentration is very close to its limit for the 12-h shifts. If the diesel machines are not properly maintained, their $\mathrm{CO}$ emissions will increase and may exceed the limit for 12-h shifts as well as the limit for 8-h shifts. Section 7 discusses these results.

This planned peak demand seldom happens in reality because all trucks are rarely in the mine at the same time. Therefore, a scenario based on the planned actual demand (based on the planned actual number of trucks in the mine at the same time) must be considered.

\subsection{Scenario of Using VOD and Diesel Machines}

For this scenario, VOD was initially excluded from VentSim simulations (all fans were run at their maximum speed) to see what would happen to diesel exhaust contaminant concentrations and temperature when the planned actual demand of airflow was used as the basis instead of the planned peak demand. Table 9 shows the highest predicted values of diesel exhaust contaminant concentration, temperature, and radon exposure in these simulations. The estimated annual ventilation and heating power consumption and costs remain the same as shown in Table 7. However, Table 9 indicates that using the planned actual demand as the design basis reduces the predicted diesel exhaust contaminant concentration and the temperature. Both are now well below their limit. The area with the highest predicted temperature is no longer the main ramp; it is now the west loading bay in level 486 because only three trucks are running on the main
Table 9 Highest predicted values of diesel exhaust contaminant concentration, temperature, and radon exposure for the planned actual demand of airflow without VOD

\begin{tabular}{lll}
\hline Item & Highest value & Area \\
\hline $\mathrm{CO}$ & $6.1 \mathrm{ppm}$ & Main ramp \\
$\mathrm{NO}_{2}$ & $0.08 \mathrm{ppm}$ & Main ramp \\
$\mathrm{DPM}$ & $0.011 \mathrm{mg} / \mathrm{m}^{3}$ of EC & Main ramp \\
Temperature & $22^{\circ} \mathrm{C} \mathrm{WB}$ & Level 486 west loading bay \\
Radon & $1.4 \mathrm{MBqh} / \mathrm{m}^{3}$ per year & Level 536 west footwall drive \\
\hline
\end{tabular}

Limits: CO: 20 ppm for 8-h shifts and 10 ppm for 12-h shifts; $\mathrm{NO}_{2}$ : $0.5 \mathrm{ppm}$ for 8 -h shifts and $0.25 \mathrm{ppm}$ for 12 -h shifts; DPM (current): $0.1 \mathrm{mg} / \mathrm{m}^{3}$ of EC for $8-\mathrm{h}$ shifts and $0.05 \mathrm{mg} / \mathrm{m}^{3}$ of EC for $12-\mathrm{h}$ shifts; DPM (after February 26, 2026): $0.05 \mathrm{mg} / \mathrm{m}^{3}$ of EC for 8-h shifts and $0.025 \mathrm{mg} / \mathrm{m}^{3}$ of EC for 12-h shifts; temperature: $27{ }^{\circ} \mathrm{C} \mathrm{WB}$; radon: $2.1 \mathrm{MBqh} / \mathrm{m}^{3}$ per year

ramp when the planned actual demand is used as the basis, but eight trucks are running when the planned peak demand is used as the basis.

The values shown in Table 9 indicate that VOD can be used to reduce ventilation and heating power consumption. To get these values, the study simulated a system that automatically reduced the speed of primary, secondary, and crosscut fans while maintaining these values below their limit and maintaining a minimum air velocity of $0.3 \mathrm{~m} / \mathrm{s}$ in horizontal airways. After several iterations, it was found that reducing the speed of primary, secondary, and crosscut fans to $80 \%$ met this aim. In this new setting, the primary intake airflow was reduced to $88 \mathrm{~m}^{3} / \mathrm{s}$, and airflow on each level was reduced to around $29 \mathrm{~m}^{3} / \mathrm{s}$. Table 10 shows the estimated annual ventilation and heating power consumption and costs for this scenario and their savings relative to the baseline costs (values shown in Table 7). The relative savings for primary and secondary fans' power are greater than for heating power because the fan power is proportional to the cube of airflow quantity, while the heating power is proportionally linear to the airflow quantity. However, in monetary terms, the heating cost reduction are the most significant because it represents $61 \%$ of the overall power cost reduction. Table 11 shows the highest predicted values of diesel exhaust contaminant concentration, temperature, and radon exposure for this scenario; all are below their limits. The speed of the fans cannot be reduced further because it would cause the air velocity in the footwall drives and production drives to drop below $0.3 \mathrm{~m} / \mathrm{s}$.

Results in this scenario and the previous one show the upgrading of the existing primary fans can be avoided, and using VOD can reduce ventilation and heating power costs. This is further discussed in Sect. 7. 
Table 10 Estimated annual ventilation and heating power consumption and costs for the scenario of using VOD and diesel machines, and their savings relative to baseline costs

\begin{tabular}{|c|c|c|c|c|c|c|}
\hline \multicolumn{2}{|l|}{ Primary fans' power } & \multicolumn{2}{|c|}{ Secondary and crosscut fans' power } & \multicolumn{2}{|l|}{ Heating power } & \multirow[t]{2}{*}{ Total power costs (SEK) } \\
\hline Consumption (kW) & Cost (SEK) & Consumption (kW) & Cost (SEK) & Consumption $(\mathbf{k W})$ & Cost (SEK) & \\
\hline 51.1 & 313,345 & 165.1 & $1,012,393$ & 2529.4 & $9,008,654$ & $10,334,392$ \\
\hline \multicolumn{2}{|c|}{ Cost saving: 312,119 SEK } & \multicolumn{2}{|c|}{ Cost saving: 971,309 SEK } & \multicolumn{2}{|c|}{ Cost saving: 2,047,421 SEK } & $\begin{array}{l}\text { Cost saving: 3,330,849 } \\
\text { SEK }\end{array}$ \\
\hline \multicolumn{2}{|l|}{$\%$ saving: $50 \%$} & \multicolumn{2}{|l|}{$\%$ saving: $49 \%$} & \multicolumn{2}{|l|}{$\%$ saving: $18.5 \%$} & $\%$ saving: $24 \%$ \\
\hline
\end{tabular}

\subsection{Scenario of Using VOD and BEVs}

Several iterations of reducing the speed of primary, secondary, and crosscut fans were performed until temperature and radon exposure fell below their limits, and the air velocity in horizontal airways was no less than $0.2 \mathrm{~m} / \mathrm{s}$. It was found that the speed of primary, secondary, and crosscut fans can be reduced to $70 \%$ when the primary intake airflow is reduced to $77 \mathrm{~m}^{3} / \mathrm{s}$ and airflow in each level is reduced to around $25.5 \mathrm{~m}^{3} / \mathrm{s}$. Table 12 shows the estimated annual ventilation and heating power consumption and costs for this scenario and their savings relative to the baseline costs (values shown in Table 7). As in Table 10, the relative savings for primary and secondary fans' power are greater than those for heating power. However, in monetary terms, the heating cost reduction are the most significant because it represents $65 \%$ of the overall power cost reduction. Table 13 shows the highest predicted temperature and radon exposure for this scenario; both are below their limits, and the air quality is greatly improved, as all diesel exhaust contaminants are removed by replacing diesel machines with BEVs. This table shows the predicted radon exposure in level 536 west footwall drive is very close to its limit, thus preventing further reduction of the speed of the fans.

Results for this scenario show that using VOD and BEVs can further reduce Konsuln's ventilation and heating power costs.

Table 11 Highest predicted values of diesel exhaust contaminant concentration, temperature, and radon exposure for the scenario of using VOD and diesel machines

\begin{tabular}{lll}
\hline Item & Highest value & Area \\
\hline $\mathrm{CO}$ & $7.6 \mathrm{ppm}$ & Main ramp \\
$\mathrm{NO}_{2}$ & $0.095 \mathrm{ppm}$ & Main ramp \\
$\mathrm{DPM}$ & $0.014 \mathrm{mg} / \mathrm{m}^{3}$ of EC & Main ramp \\
Temperature & $23^{\circ} \mathrm{C} \mathrm{WB}$ & Level 486 west loading bay \\
Radon & $1.7 \mathrm{MBqh} / \mathrm{m}^{3}$ per year & Level 536 west footwall drive \\
\hline
\end{tabular}

Limits: CO: 20 ppm for 8-h shifts and 10 ppm for 12-h shifts; $\mathrm{NO}_{2}$ : $0.5 \mathrm{ppm}$ for 8 -h shifts and $0.25 \mathrm{ppm}$ for 12 -h shifts; DPM (current): $0.1 \mathrm{mg} / \mathrm{m}^{3}$ of EC for 8 -h shifts and $0.05 \mathrm{mg} / \mathrm{m}^{3}$ of EC for 12 -h shifts; DPM (after February 26, 2026): $0.05 \mathrm{mg} / \mathrm{m}^{3}$ of EC for 8-h shifts and $0.025 \mathrm{mg} / \mathrm{m}^{3}$ of EC for $12-\mathrm{h}$ shifts; temperature: $27{ }^{\circ} \mathrm{C} \mathrm{WB}$; radon: $2.1 \mathrm{MBqh} / \mathrm{m}^{3}$ per year
However, the reduction is restricted by radon exposure in level 536 west footwall drive. This is further discussed in Sect. 7.

\subsection{Scenario of Using BEVs Only}

In this scenario, the ventilation and heating power costs and the airflow quantities were the same as those in the baseline scenario since VOD was not available. Table 14 shows the highest predicted temperature and radon exposure for this scenario; both are well below their limits, and the air quality is greatly improved, as all diesel exhaust contaminants are removed by replacing diesel machines with BEVs.

The speed of primary, secondary, and crosscut fans can be reduced to $70 \%$ as in VOD and BEV scenario to save power costs and maintain temperature and radon exposure below their limits and keep air velocity at no less than $0.2 \mathrm{~m} / \mathrm{s}$. However, this must be done manually, as VOD is not used. As in the previous scenario, the reduction of the speed of the fans is restricted by radon exposure in level 536 west footwall drive.

The aim of this scenario was to investigate whether using BEVs as a standalone strategy is feasible. The results indicate that it is feasible, but with a caveat: the speed of primary, secondary, and crosscut fans must be reduced manually. Alternatively, these fans could be replaced with the smaller ones without VOD. Does this mean VOD does not need to be installed? This is discussed in Sect. 7.

\section{Results of the Assessment of the Suitability of Nordic and Canadian Heating Power Reduction Strategies}

As the previous section notes, heating power comprises the largest portion of Konsuln's ventilation and heating power costs, making it advisable to investigate additional strategies to reduce it. Three heating power reduction strategies are used or have been used in the Nordic countries and Canada: 
Table 12 Estimated annual ventilation and heating power consumption and costs for the scenario of using VOD and BEVs, and their savings relative to baseline costs

\begin{tabular}{|c|c|c|c|c|c|c|}
\hline \multicolumn{2}{|l|}{ Primary fans' power } & \multicolumn{2}{|c|}{ Secondary and crosscut fans' power } & \multicolumn{2}{|l|}{ Heating power } & \multirow[t]{2}{*}{ Total power costs (SEK) } \\
\hline Consumption (kW) & Cost (SEK) & Consumption (kW) & Cost (SEK) & Consumption $(\mathbf{k W})$ & Cost (SEK) & \\
\hline 34.5 & 211,554 & 111.2 & 681,878 & 2213.2 & $7,882,572$ & $8,776,004$ \\
\hline \multicolumn{2}{|c|}{ Cost saving: 413,910 SEK } & \multicolumn{2}{|c|}{ Cost saving: $1,301,824$ SEK } & \multicolumn{2}{|c|}{ Cost saving: 3,173,503 SEK } & $\begin{array}{l}\text { Cost saving: 4,889,237 } \\
\text { SEK }\end{array}$ \\
\hline \multicolumn{2}{|l|}{$\%$ saving: $66 \%$} & \multicolumn{2}{|l|}{$\%$ saving: $66 \%$} & \multicolumn{2}{|l|}{$\%$ saving: $29 \%$} & $\%$ saving: $36 \%$ \\
\hline
\end{tabular}

1. Exhaust air heat recovery system is used in Kiruna mine [28] and Zinkgruvan mine [29]. Both mines are in Sweden.

2. Natural Heat Exchange Area (NHEA), also called seasonal thermal energy storage (SeTES), is used in Creighton mine in Canada [30-32].

3. Ice stope was used in Stobie mine in Canada [30, 33].

\subsection{Exhaust Air Heat Recovery System}

This system requires the main intake and exhaust airways to be very close to each other. In Konsuln, the distance between the intake shaft (main intake airway) and the main ramp portal (main exhaust airway) is about $800 \mathrm{~m}$. Therefore, this system is not suitable for Konsuln.

\subsection{NHEA/SeTES}

Since this heating method relies on a caving zone, it may be suitable for Konsuln, as it uses SLC mining method. However, it cannot be used in Konsuln for the following reasons:

1. Intake ventilating air can be drawn through the NHEA/ SeTES at Creighton because its caving zone has constant geometry and thus constant permeability and resistance. SLC was used to extract the upper ore body at Creighton mine; then, the mining method transitioned to stoping mining methods. In Konsuln, SLC is used throughout the life of the mine. This means the geometry of the caving zone and thus its permeability and resistance change

Table 13 Highest predicted values of temperature and radon exposure for the scenario of using VOD and BEVs

\begin{tabular}{llc}
\hline Item & Highest value & Area \\
\hline Temperature & $18{ }^{\circ} \mathrm{C} \mathrm{WB}$ & $\begin{array}{c}\text { Level } 486 \\
\text { west } \\
\end{array}$ \\
& & loading \\
& & bay \\
& & Level 536 \\
Radon & $2 \mathrm{MBqh} / \mathrm{m}^{3}$ per year & west \\
& & footwall \\
& & drive \\
\hline
\end{tabular}

Limits: temperature: $2{ }^{\circ} \mathrm{C} \mathrm{WB}$; radon: $2.1 \mathrm{MBqh} / \mathrm{m}^{3}$ per year every day. A mine cannot have a main intake airway whose resistance changes continuously.

2. Most importantly, there is radon in Konsuln's caving zone. Experience in Kiruna and Malmberget shows the best way to manage radon in SLC mines is to keep it inside the caving zone as much as possible. A primary exhaust system like the one used in Creighton (NHEA/ SeTES is a part of it) cannot be used in these mines because radon will be flushed from the caving zone into the intake airways. Konsuln employs the force primary system during steady-state production to create positive pressure inside the caving zone. Note that Creighton does not have radon in its ore body.

\subsection{Ice Stope}

This method requires large unfilled stopes located near the surface. It cannot be used in Konsuln because SLC does not create stopes. This method is only suitable for mines that use SLOS as their mining method and have low in situ stresses in shallow depth that allow shallow stopes to remain unfilled.

\section{Discussion}

\subsection{Justification of Using VOD}

Section 5.1 shows the existing system can still cater to the planned production rate of $3 \mathrm{Mtpa}$ at the peak demand of

Table 14 Highest predicted values of temperature and radon exposure for the scenario of using BEVs only

\begin{tabular}{llc}
\hline Item & Highest value & Area \\
\hline Temperature & $16.5^{\circ} \mathrm{C} \mathrm{WB}$ & $\begin{array}{c}\text { Level } 486 \\
\text { west } \\
\\
\end{array}$ \\
& & loading \\
& bay \\
& & Level 536 \\
Radon & $1.4 \mathrm{MBqh} / \mathrm{m}^{3}$ per year & west \\
& & footwall \\
& & drive \\
\hline
\end{tabular}

Limits: temperature: $27{ }^{\circ} \mathrm{C} \mathrm{WB}$; radon: $2.1 \mathrm{MBqh} / \mathrm{m}^{3}$ per year 
the airflow for both 8- and 12-h working shifts because diesel exhaust contaminants, temperature, and radon are below their limits. These results are surprising, but they indicate the Euro VI compliant engines are so clean that the diesel contaminant emissions remain below their limit, even though the number of machines and the diesel power are higher than those used for the production rate of 0.8 Mtpa. However, it must be noted that the contaminant emission rates of the Euro VI compliant engines used in the diesel exhaust simulation are for brand new engines. These values can change for the worse when the engines are poorly maintained, and this often happens in reality. The low contaminant emission rates depend heavily on the good operation of the aftertreatment devices. Poor maintenance of these devices can increase the contaminant emission rates [34]. Therefore, it is crucial that LKAB's maintenance department performs good maintenance on Konsuln's diesel fleet.

Sect 5.1 and 5.2 show using VOD can avoid the need to upgrade the existing primary fans and can reduce ventilation and heating power costs. Sect 5.3 shows using VOD and BEVs can further reduce these costs, but this reduction is restricted by radon exposure in level 536 west footwall drive. This prevents the speed of the fans from being reduced below $70 \%$. The radon exposure was estimated based on the predicted emanation rate of $5 \mathrm{~Bq} / \mathrm{m}^{2} \mathrm{~s}$ (see Appendix 1) and the annual working period of $1804 \mathrm{~h}$. If the actual emanation rate is less than this predicted value and/or the working period is reduced in the future, the speed of the fans can be further reduced; thus, ventilation and heating power costs can also be further reduced.

Section 5.4 shows using BEVs alone can achieve the same reduction as using VOD and BEVs, with a caveat: the speed of the fans must be reduced manually. This avoids the expensive capital investment required to install VOD. However, BEVs are still not well tested in LKAB mines; therefore, this strategy is riskier than VOD, which is successfully operated in other LKAB mines. This is why VOD was selected as the first considered strategy; moreover, as Sect. 5.2 shows, it can reduce Konsuln's ventilation and heating power costs in the future. The other alternative, which is replacing primary, secondary, and crosscut fans with smaller ones, would cost additional money and delay the development and production, which disqualifies it from further consideration.

Another reason why VOD should be installed, even if BEVs are used, is the blasting re-entry time. Reducing airflow quantity extends the re-entry time. A re-entry time simulation using VentSim Design indicates that reducing the speed of primary, secondary, and crosscut fans by $70 \%$ increases the re-entry time into a level after a production blasting by about an hour, even with the level exhaust fans running at full speed. Using VOD will allow the primary and secondary fans to automatically run at full speed during the clearance of the blasting fumes; their speed is automatically reduced during the steady-state production phase.

\subsection{Further Discussion of Using BEVs and Additional Heating Power Reduction Strategies}

As noted, VOD was considered first because it has been well tested in LKAB mines, while BEVs have not. However, BEVs are seen by many mines in the EU as the most feasible way to comply with the new TLV-TWA of $\mathrm{NO}_{2}$ $(0.5 \mathrm{ppm})$ and the future TLV-TWA of DPM $\left(0.05 \mathrm{mg} / \mathrm{m}^{3}\right.$ of EC). These limits are very low, and many mines consider using diesel machines makes compliance difficult, even if these machines are fitted with a Euro VI compliant engine. As mentioned in Sect. 7.1, poor maintenance could cause Euro VI compliant engines to emit higher amounts of contaminants than their design values allow. Therefore, although BEVs are not yet trialed in LKAB mines, using them would eliminate the issue of compliance with these low limits. During SIMS project field trial of BEVs in Kittilä mine, the second author of this paper observed that no gases encountered in the trial area [35]. Using them would also be in line with LKAB's strategy to achieve zero carbon emissions by 2045. Recall that LKAB has ordered ST14 Battery LHDs and MT42 Battery trucks for the SUM project and ST18 Battery LHDs will be trialed later in the same project. These will improve LKAB's experience with BEVs.

Since BEVs represent relatively new technology in underground mining worldwide, many of their safety aspects are not well understood. One is fire safety. There are no reliable input data for BEV fire simulation in VentSim Design or other ventilation simulation software. Therefore, fire safety studies should be carried out in the future, similar to the study on a diesel LHD by Hansen and Ingason [36].

The safe deployment of BEVs has the potential for an old idea to be reused: controlled partial recirculation (CPR) [37-39]. CPR can reduce a mine's heating power costs, as the exhaust air is warmer than the intake air [39]. The mining industry remains reluctant to use this technique even though a trial in Mount Isa copper mine in Australia showed the contaminant level in the mixed intake air did not increase beyond unacceptable levels when this technique was used [37]. Introducing "dirty air" into an intake airway, even if it is reconditioned, marks a radical change in current thinking. Replacing diesel machines with BEVs will make the exhaust air much cleaner and may allow it to be recirculated. A feasibility study on using CPR when BEVs are used should be done in the future.

Sect. 6 shows none of the three heating reduction strategies used in Nordic countries and Canada is suitable for Konsuln because each requires specific conditions that are not present in Konsuln. A Canadian prototype strategy that might be suitable is Modular Thermal Transfer Unit (MTTU) 
[40, 41]. It is essentially a portable surface ice stope, built by stacking three modified sea shipping containers, which are then sprayed with foam insulation. The unit was built to investigate the feasibility of a less maintenance-intensive alternative to the Stobie mine ice stope; it required extensive maintenance because there was limited access, and the infrastructure was aging. The unit only reached testing stage. The preliminary results from the tests showed the unit could heat cold air when it was below $-6{ }^{\circ} \mathrm{C}$ to near $0{ }^{\circ} \mathrm{C}$. However, the tests also discovered some problems that must be solved to make the unit operational. Nevertheless, this unit has the potential to be considered as an additional heating reduction strategy, if the problems discovered during the tests are ironed out.

\section{Conclusions}

Based on the preceding discussion, using VOD in Konsuln mine can be justified. Even though the existing system can still handle the most challenging design case (increasing production rate to $3 \mathrm{Mtpa}$ ), using VOD can reduce ventilation and heating power costs and simultaneously keep the blasting re-entry time as short as possible. However, it must be noted that the justification outlined in this paper is based on operating costs only. This is because the financial analysis, which includes both capital and operating costs, could not be disclosed due to the confidentiality of the capital costs data. Nevertheless, the authors are allowed to disclose the rough estimation of the payback period, which is about 1.5 years. Therefore, using VOD in Konsuln mine is also justifiable from financial point of view.

Using BEVs along with VOD or using BEVs as a standalone strategy can further reduce these costs. However, BEVs are currently considered a riskier strategy; they have not been well tested in LKAB mines, while VOD is more commonly operated. Nevertheless, using BEVs will significantly improve the air quality and eliminate the issue of compliance with the low prescribed concentration limits of $\mathrm{NO}_{2}$ and DPM. Using them would also be in line with LKAB's strategy to achieve zero carbon emissions by 2045 . It must be noted that LKAB mines are connected to the state electrical power grid that generates its power from zero carbon system (hydroelectric power plant). Trials of Epiroc BEVs in the SUM project will improve LKAB's experience with this strategy.

The presence of radon restricts the reduction of ventilation and heating power costs when BEVs are used. The magnitude of the restriction is proportional to the amount of radon present in the mine. This restriction will be lessened if the actual emanation rate is less than the predicted value used in the VentSim simulation and/or the annual working period in Konsuln is reduced.
As for additional strategies to reduce heating power costs, none of the strategies used in Nordic countries and Canada is suitable, as each requires specific conditions that are not present in Konsuln. However, the old idea of CPR and the prototype strategy of MTTU might be suitable, if all issues related to them are sorted out.

\section{Appendix 1. VentSim Design simulation input data}

Diesel Exhaust Simulation.

- Yield rate of diesel exhaust contaminants $\left(\mathrm{CO}, \mathrm{NO}_{\mathrm{x}}\right.$, and DPM) in gram per kilowatt-hour ( $\mathrm{g} / \mathrm{kWh}$ ) for Euro VI compliant engine. This data was obtained from Scania and Epiroc. Due to the request from the machines' manufacturers, this data is regarded as confidential and therefore the values cannot be stated in this paper.

- Rated engine power of Scania R500 truck and Epiroc ST18 LHD, which are $373 \mathrm{~kW}$ and $352 \mathrm{~kW}$ respectively.

- All machines are assumed to run at $45 \%$ of their engine rated power, based on LKAB's experience.

Heat Simulation.

- Surface climate in Kiruna during summer, which is the average surface temperatures and barometric pressure during summer. This is obtained from Institute of Meteorology and Hydrology of Sweden (Sveriges meteorologiska och hydrologiska institut-SMHI) website. It was found that average summer temperatures in Kiruna are $12.6{ }^{\circ} \mathrm{C} \mathrm{DB}$ and $7.5^{\circ} \mathrm{C} \mathrm{WB}$, and average summer barometric pressure in Kiruna is $94.3 \mathrm{kPa}$.

- Rock thermal parameters. All of these values are assumptions. The values of thermal conductivity and diffusivity are based on the laboratory measurement values of quartzite, which is the predominant rock type in Konsuln. They are stated in VentSim Design user manual. The surface VRT and geothermal gradient are based on measured value in a Canadian mine that is located in a similar climatic region. The wetness fraction is the default value in VentSim Design software and is considered as average wetness in many mines worldwide based on a discussion with Mr. Craig Stewart, the creator of the software. Konsuln mine is a not a wet mine and can be considered as having average wet condition.

- Thermal conductivity: $3.0 \mathrm{~W} / \mathrm{m}^{\circ} \mathrm{C}$

- Thermal diffusivity: $1.39 \times 10^{-6} \mathrm{~m}^{2} / \mathrm{s}$

- Surface VRT: $1{ }^{\circ} \mathrm{C}$

- Geothermal gradient: $1{ }^{\circ} \mathrm{C}$ per $100-\mathrm{m}$ increase of depth

- Wetness fraction: $15 \%$ 
BEV Heat Simulation.

- Rated motor power of MT42 battery and LH518B LHD, which are $400 \mathrm{~kW}$ and $540 \mathrm{~kW}$ respectively.

- All machines are assumed to run at $45 \%$ of their rated motor power, based on LKAB's experience.

\section{Radon Simulation.}

- Predicted radon emanation rate in each production level, $5 \mathrm{~Bq} / \mathrm{m}^{2} \mathrm{~s}$. This was backcalculated in VentSim Design using Konsuln's latest radon monitoring data.

\section{Appendix 2. Calculations of gases and DPM concentration limit for 12-h working shift using Brief and Scala method}

Brief and Scala method to calculate concentration limit for working period with duration other than $8 \mathrm{~h}$ is as follows:

Adjusted limit for $h$ working hours per day $=\frac{8 \times(24-h) \times \text { TLV TWA }}{16 \times h}$

Using this method, the gases' and DPM's limit for 12-h shift is calculated as half of their TLV-TWA.

Acknowledgements The authors are grateful to Mr. Michael Lowther, manager of Konsuln mine, and Dr. Matthias Wimmer, manager of mining technology, Kiruna mine, for permission to write this paper. The authors are also grateful to Ms. Stina Klemo, Ventilation Engineer, Kiruna mine, for her assistance in data collection for this study.

Author Contribution SG calibrated ventilation models that were used in this study, carried out all ventilation simulations and analyzed their results, and wrote the first draft of the manuscript.

AH supervised calibration of ventilation models, supervised all ventilation simulations, checked results of ventilation simulations, reviewed the first draft of the manuscript, and reviewed the suitability of heating power reduction strategies that have been used in the Nordics and Canada.

AM provided all information related to $L K A B$ and did the final review of the manuscript.

Funding Open access funding provided by Lulea University of Technology.

\section{Declarations}

Conflict of Interest The authors declare no competing interests.

Open Access This article is licensed under a Creative Commons Attribution 4.0 International License, which permits use, sharing, adaptation, distribution and reproduction in any medium or format, as long as you give appropriate credit to the original author(s) and the source, provide a link to the Creative Commons licence, and indicate if changes were made. The images or other third party material in this article are included in the article's Creative Commons licence, unless indicated otherwise in a credit line to the material. If material is not included in the article's Creative Commons licence and your intended use is not permitted by statutory regulation or exceeds the permitted use, you will need to obtain permission directly from the copyright holder. To view a copy of this licence, visit http://creativecommons.org/licenses/by/4.0/.

\section{References}

1. Luossavaara Kiirunavaara Aktiebolag (LKAB) website. https:// www.lkab.com/en/about-lkab/from-mine-to-port/mining/.

2. Sustainable Underground Mining (SUM) website. https://susta inableundergroundmining.com/.

3. Mining Magazine (2018). Electric approach saves ventilation costs at Borden. https://www.miningmagazine.com/sustainability/news/ 1347608/electric-approach-saves-ventilation-costs-at-borden.

4. Arbetsmiljöverket, (2018). AFS 2018:1 Hygieniska gränsvärden (in Swedish). https://www.av.se/globalassets/filer/publikationer/ foreskrifter/hygieniska-gransvarden-afs-2018-1.pdf.

5. European Union Commission (2017). Commission Directive (EU) 2017/164 of 31 January 2017 establishing a fourth list of indicative occupational exposure limit values pursuant to Council Directive 98/24/EC, and amending Commission Directives 91/322/EEC, 2000/39/EC and 2009/161/EU (Text with EEA relevance). https://eur-lex.europa.eu/legal-content/EN/TXT/PDF/? uri=CELEX:32017L0164\&from $=E N$.

6. Halim A, Bolsöy T, Klemo S (2020) An overview of the Nordic mine ventilation system. CIM Journal 11(2):111-119

7. European Union Commission (2019). Directive (EU) 2019/130 of The European Parliament and of The Council of 16 January 2019 amending Directive 2004/37/EC on the protection of workers from the risks related to exposure to carcinogens or mutagens at work. https://eur-lex.europa.eu/legal-content/EN/TXT/PDF/? uri=CELEX:32019L0130\& from $=$ FR.

8. Safe Work Australia (2015). Guide to managing risks of exposure to diesel exhaust in the workplace. Retrieved from https://www. safeworkaustralia.gov.au/system/files/documents/1702/guidancemanaging-risks-exposure-diesel-exhaust-in-the-workplace.pdf.

9. Safe Work Australia (2019). Workplace exposure standards for airborne contaminants. Retrieved from https://www.safeworkau stralia.gov.au/system/files/documents/1912/workplace-exposurestandards-airborne-contaminants.pdf.

10. Government of Western Australia (1983). Radiation Safety (General) Regulations 1983. Retrieved from https://www.slp.wa.gov. au/statutes/regs.nsf/(DownloadFiles)/Radiation+Safety+(Gener al)+Regulations+1983.pdf/\$file/Radiation+Safety+(General)+ Regulations+1983.pdf.

11. Government of Ontario (2020). Current Occupational Exposure Limits for Ontario Workplaces Required under Regulation 833. Retrieved from https://www.labour.gov.on.ca/english/hs/pubs/oel_ table.php\#qr.

12. Apel, D.B. and Hashiho, Z. (2011). Radiaton control, in SME mining engineering handbook, $3^{\text {rd }}$ edition, (Ed. P. Darling). Society of Mining, Metallurgy, and Exploration (SME), Littleton, Colorado, USA, pp. 1625-1632.

13. Mine Safety and Health Administration (MSHA) (2018a). 30 Code of Federal Regulations (CFR) part 7 subpart E Diesel engines intended to be used in underground coal mines, regulation 7.84, pp. 32. Retrieved from https://www.govinfo.gov/conte nt/pkg/CFR-2018-title30-vol1/pdf/CFR-2018-title30-vol1.pdf.

14. Mine Safety and Health Administration (MSHA) (2018b). 30 Code of Federal Regulations (CFR) part 70 subpart B Dust standards, regulation 70.100 , pp. 454. Retrieved from https://www. govinfo.gov/content/pkg/CFR-2018-title30-vol1/pdf/CFR-2018title30-vol1.pdf.

15. Mine Safety and Health Administration (MSHA) (2018c). 30 Code of Federal Regulations (CFR) part 57 subpart D Air quality, radiation, 
physical agents, and diesel particulate matter, regulation 57.5060, pp. 372. Retrieved from https://www.govinfo.gov/content/pkg/CFR-2018title30-vol1/pdf/CFR-2018-title30-vol1.pdf.

16. Stanton DW, du Plessis JJL, Belle BK (2014) Occupational exposure limits for airborne pollutants. In: du Plessis JJL (ed) Ventilation and occupational environment engineering in mines. Mine Ventilation Society of South Africa, Johannesburg, pp 237-254

17. Mining Education Australia - MEA (2006). Course note on metalliferous mine ventilation planning and practice.

18. Rönnblom, W. (1996). Ventilation-by-demand. Proceedings $9^{\text {th }}$ Canadian Institute of Mining, Metallurgy, and Petroleum (CIM) Operator's Conference. CIM, Westmount, Canada.

19. Nensen, P. and Lundkvist, A. (2005). From $167 \mathrm{GwH}$ to 72 $\mathrm{GwH}$ - ventilation on demand in LKAB's iron ore mine, Malmberget. Proceedings of the IPPC Conference, Innovative Energy Efficiency Examples of Different Industrial Sectors - Energy Efficiency in Cement, Metal and Petrochemical Industry, Vienna, Austria,

20. Isaksson, M., Andersson, P., and Ekenstedt, F. (2009). Ventilation on demand (VOD) systems used by Boliden Mineral AB, Kristineberg mine, $1987-2008$. Proceedings of $9^{\text {th }}$ International Mine Ventilation Congress, pp. 105-112. Oxford and IBH Publishing, New Delhi, India.

21. Burman, J. and Markström, A. (2016). Ventilation on demand in Kankberg mine. https://mobilaris.se/wp-content/uploads/2019/07/ VoD-Kankberg-paper-2016-07-12.pdf.

22. Tran-Valade, T. and Allen, C. (2013). Ventilation on demand key considerations for the business case. Proceedings of CIM Conference 2013, Toronto, Canada.

23. Sustainable Intelligent Mining Systems (SIMS) website. https:// www.simsmining.eu/project/battery-driven-equipment/.

24. Epiroc's Battery as a Service (BaaS) website. https://www.epiroc. com/en-us/products/parts-and-services/batteries-as-a-service.

25. Halim, A. (2019). Sustainable Intelligent Mining Systems (SIMS) project—battery-powered mining equipment (BME). Presentation at Canadian Institute of Mining, Metallurgy, and Petroleum (CIM) Convention 2019, Montreal.

26. Gyamfi, S., Halim, A., and Martikainen, A. (2021). Calibration of LKAB's Konsuln test mine ventilation model using barometer Pressure-Quantity (PQ) Survey. Proceedings of $18^{\text {th }}$ North American Mine Ventilation Symposium, pp. 23-33. CRC Press/ Balkema, Leiden, the Netherlands.

27. McPherson MJ (2009) Subsurface ventilation engineering. Mine Ventilation Services Inc, Fresno, California, USA, p 824

28. Linder, K. (2011). Värmeåtervinning av gruvventilationsluft LKAB i Kiruna (in Swedish) (Master's thesis). University of Umeå, Sweden. Retrieved from https://www.diva-portal.org/ smash/get/diva2:550508/FULLTEXT01.pdf

29. Holmlund, K. (2015). Heat recovery solutions for mine ventilation systems (Master's thesis). University of Karlstad, Sweden. Retrieved from http://www.diva-portal.se/smash/get/diva2: 823877/fulltext01.pdf

30. Stachulak, J. (1989). Ventilation strategy and unique air conditioning at Inco Limited. Proceedings of $4^{\text {th }}$ US Mine Ventilation Symposium, pp. 3-9. University of California Berkeley, USA.
31. Fava, L., Millar, D., Anderson, B., Schafrik, S., O'Connor, D., \& Allen, C. (2012). Modeling of the natural heat exchange area at Creighton Mine for operational decision support. Proceedings of 14th U.S./North American Mine Ventilation Symposium, pp. 351-358. The University of Utah, Salt Lake City, USA.

32. Ghoreishi-Madiseh, S.A., Sasmito, A.P., Hassani, F., Amiri, L. (2015). Heat transfer analysis of large scale seasonal thermal energy storage for underground mine ventilation. Energy Procedia vol. 75, August 2015, pp. 2093-2098. https://www.sciencedir ect.com/science/article/pii/S1876610215010929.

33. Trapani, K. (2019). Techno-economic of an ice stope thermal storage for mine heating and cooling in sub-arctic climates. Proceedings of $17^{\text {th }}$ North American Mine Ventilation Symposium, pp. 709-715. Canadian Institute of Mining, Metallurgy and Petroleum (CIM), Montreal, Canada.

34. Hines, J. (2019). The role of emissions based maintenance to reduce diesel exhaust emissions, worker exposure and fuel consumption ( $\mathrm{PhD}$ thesis). The University of Wollongong, Australia. Retrieved from https://ro.uow.edu.au/cgi/viewcontent.cgi?article= $1857 \&$ context $=$ theses 1

35. Halim, A. (2020). WP6 Final Report. Confidential report to the European Union (EU) Commission as a deliverable of Sustainable Intelligent Mining Systems (SIMS) project.

36. Hansen, R. and Ingason, H. (2013). Full-scale fire experiments with mining vehicles in an underground mine. Research Report 2013:2. Mälardalen University, Västerås, Sweden. http://www. diva-portal.org/smash/get/diva2:641036/FULLTEXT01.pdf.

37. Wu HW, Gillies ADS, Nixon AC (2001) Trial of controlled partial recirculation of ventilation air at Mount Isa Mines. Min Technol: Trans Inst Min Metall 110(2):86-96

38. Bluhm, S.J. and Funnell, R.C. (2014). Controlled recirculation of ventilation - why is this not applied more often to save energy? Proceedings of 10th International Mine Ventilation Congress, pp. 21-29. Mine Ventilation Society of South Africa, Johannesburg, South Africa.

39. Hall, A.E., McHaina, D., and Hardcastle, S.G. (1988). The use of controlled recirculation to reduce heating costs in Canada. Proceedings of $4^{\text {th }}$ International Mine Ventilation Congress, pp. 301-307. The Australasian Institute of Mining and Metallurgy (AusIMM), Melbourne, Australia.

40. Allen, C., Morgan, J., and Rantanen, E. (2012). Modular thermal transfer unit (MTTU) - portable surface ice stope. Proceedings of $14^{\text {th }}$ North American Mine Ventilation Symposium, pp. 359-364. University of Utah, Salt Lake City, USA.

41. Li, G., Butler, K., Hardcastle, S., Morgan, J., and Allen, C. (2017). Testing and evaluation of a Modular Thermal Transfer Unit for underground mine air conditioning. Proceedings of $16^{\text {th }}$ North American Mine Ventilation Symposium, pp. 4-1 to 4-8. Colorado School of Mines, Golden, USA.

Publisher's Note Springer Nature remains neutral with regard to jurisdictional claims in published maps and institutional affiliations. 